\title{
The Life Philosophy of the Banjarese as a Value Education in Learning History
}

\author{
Dewicca Fatma Nadilla \\ Postgraduate Program of Historical Education, Sebelas Maret University, Surakarta \\ dewiccanadilla@gmail.com
}

\begin{tabular}{ccc}
\hline Received & Accepted & Published \\
$10 / 04 / 2017$ & $01 / 06 / 2017$ & $31 / 07 / 2017$ \\
\hline & DOI & \\
& $10.26523 /$ yupa.v1i2.53 \\
\hline
\end{tabular}

\begin{abstract}
Banjar people known as nomads and merchants in his life is famous for the principle that formed the character of the Banjar. Through the values contained in the philosophy/life principle of the Banjar people who can then be integrated into the world of education, one of which is historical education. The meaning and value of local wisdom existing in the community has a goal to increase learners to be able to develop their attributes derived from wisdom and local history of society, possessed the skill in understanding the society in the life of the process and possessing the characteristics and attitudes that are in line with the value of local wisdom. Amid the onslaught of technology and practicality of life offered, later emerged an approach that tried to highlight the local wisdom owned by the region, especially South Kalimantan. Therefore, the purpose of this paper is to introduce the value of the urban life of Banjar philosophy and its integration in learning history as a form of cultural endurance. The method used in this writing that is with a qualitative approach and data collection is done by library study by collecting the relevant literature with this paper.
\end{abstract}

Keywords: Philosophy of Life, Banjar People, Local Wisdom.

\begin{abstract}
Abstrak Orang Banjar yang dikenal sebagai pengembara dan pedagang dalam hidupnya terkenal dengan prinsip yang membentuk karakter Banjar. Melalui nilai-nilai yang terkandung dalam filosofi / prinsip hidup masyarakat Banjar yang kemudian bisa diintegrasikan ke dalam dunia pendidikan, salah satunya adalah pendidikan sejarah. Kehidupan Banjar sebagai wujud ketahanan budaya setempat. Makna dan nilai kearifan lokal yang ada di masyarakat memiliki tujuan untuk meningkatkan kemampuan peserta didik untuk dapat mengembangkan atribut mereka yang berasal dari kearifan dan sejarah masyarakat setempat, memiliki keterampilan dalam memahami masyarakat dalam kehidupan proses dan memiliki karakteristik. dan sikap yang sesuai dengan nilai kearifan lokal. Di tengah gempuran teknologi dan kepraktisan hidup yang ditawarkan, kemudian muncul sebuah pendekatan yang mencoba menyoroti kearifan lokal yang dimiliki oleh daerah, terutama Kalimantan Selatan. Oleh karena itu, tujuan dari makalah ini adalah untuk mengenalkan nilai kehidupan perkotaan filsafat Banjar dan integrasinya dalam pembelajaran sejarah sebagai bentuk daya tahan budaya. Metode yang digunakan dalam penulisan ini yaitu dengan pendekatan kualitatif dan pengumpulan data dilakukan dengan studi pustaka dengan mengumpulkan literatur yang relevan dengan makalah ini.
\end{abstract}

Kata kunci : Filsafat Kehidupan, Orang Banjar, Kearifan Lokal. 


\section{INTRODUCTION}

Looking into the phenomenon of the world of education that recently happened, then we will find a focus that is seriously designed by the government, where the focus is the cultivation of values and character of the nation. The formation of values and character of the nation, of course, cannot be separated connection with the values and character of the localities of each tribe in Indonesia. Understanding the value and local character of the nation that became the focus of the curriculum requires the teacher's education to continue to grow creatively and wisely in carrying out learning, in this case, is certainly a history of learning. The education of values and character is not new. The formation of national character is even listed in the national education system law No. 20 the year 2003. The purpose of national education is to develop the potential of learners to become human beings who believe and piety to God Almighty, have a noble character, healthy, knowledgeable, capable, creative, independent, and become citizens of a democratic and responsible.

Taking into account the localization culture which is a wisdom is a concrete step in order to maintain the values and cultural heritage of the nation under the vigorous stakeholder carried out in order to preserve the culture of the nation through the local culture. One of the biggest responsible persons in this context is a teacher who as a teacher is very closely related to education in charge of providing understanding and instil mental or good character for the younger generation of the nation by integrating learning, especially learning history with the value or philosophy of life Banjar.

The value of localized wisdom is a social factor in the country's development. In the social life, there is a value system that becomes the life philosophy and guidance of society in achieving the life activities of the day. The value contained in local wisdom can be integrated into the education world one of them through local content subjects. The meanings and values of local wisdom existing in the community have a goal to bring learners together so as to be able to develop their attitudes that are sourced by wisdom local community masses, possessed a sense of belonging in understanding the society in the life of the process and possessing the features and behaviors that are exemplified by the value of local wisdom.

This can be based on the rapid degeneration of morality and character of the nation observed by the younger generation of the 21st century. Moral decline and character blurriness is not only felt in big cities but will also affect the whole community joints is no exception one of the most districts in South Kalimantan in Tabalong Regency. Based on data from the Police Resort Tabalong until 2015 there are at least 27 cases involving teenagers either as victims or perpetrators in it. As it happens and quite appealing is the circulation of sex videos by junior and senior high school students, they also had happened arrest narcotics cases in which also contains high school age students, even to cases of detention and rape. 
Based on the above cases then the character of the young generation has to the limit of standby so that education, as an institution has a very large portion in nurturing the character of the younger generation of the nation, especially the age, is quite vulnerable in the age of junior and senior high school. As we know that the school period is a formative year that is the formation of character that determines the intellectual moral foundation of a person for the rest of his life. So that the establishment or fostering of characters in accordance with the identity of the nation is very necessary and the school as an educational institution has a very big role in it. One of the concerns in the 2013 curriculum that focuses on character education is the emergence of history as an important subject characterizing character education. Where to quote an opinion from Hassan history education is a media of character education is the most powerful to form the nation's personality because in learning history contains values in every historical event that occurred. (Hasan, 2012: 3). History education is even able to develop the potential of learners to recognize the values of the nation that continues to survive, change, and even become the identity of the nation. As we know that formed national identity then also depart from the identity of a nation. Therefore it is not wrong if the formation of national character can depart from the strengthening of the character of localization through the integration of local wisdom or culture in learning. Of course in this context is learning history as a medium of values education and character of the nation.

South Kalimantan is one of the provinces on the island of Borneo, where Banjar or Banjar is the largest tribe inhabiting it. Banjar people who are famous as traders and master monks have a principle or a view of life that continues to be held in carrying out their daily activities. Where these principles then also affect the character or the character of the display of the Bohemian society. However, it is also not spared from the effects of global swift currents that continue to undermine the various joints even social life without exception including therein also view or philosophy of life, the younger generation Banjar. Therefore, it is not surprising that in the last few years, the study of local character and wisdom or local culture is being actively promoted in the context of formal schooling. Where it can be interpreted as a guard in maintaining the character and personality of the Indonesian nation to continue in accordance with the identity and national character of the Indonesian Nation. This is in accordance with the opinion of the Danu Hurip Ismadi (2015, in Purwanto, 2015) The concept of local knowledge to be a theme that is often mentioned as an answer to the problems arising from the process of development, modernization, and globalization come "from outside". Local and traditional treasures re-glance and considered as a panacea for various these issues, and is believed to be able to improve the impact of the development or progress.

Therefore, it is in this paper attempts to explore the values of philosophy or worldview Banjar include local knowledge possessed, and the charge value in view of the Lives of Banjar 
namely Gawi Manuntung, Kayuh Baimbai, and Sarabakawa: Kawa Baucap, Kawa Manggawi, Kawa Manyandang the watchword Tabalong.

\section{METHOD}

The method of writing in this paper that is through a qualitative approach, data collection is done literature study method by collecting the source literature associated with the writing of this paper.

\section{RESULT AND DISCUSSION}

\section{Values Education}

Broadly speaking the value is divided into two groups namely the values of conscience and giving values. The value of conscience is the value that exists in man and then developed to be behaviour and the way we treat others. Included in the values of conscience are honesty, courage, peace of love, self-reliability, potential, discipline, knowing limits, purity, and conformity. Giving values are values that need to be practised or given which will then be accepted as much as possible. Included in the value giving group is faithful, trustworthy, respectful, loving, affectionate, sensitive, unselfish, kind, friendly, fair and generous. (Mubarok, 2009: 7).

The initial concept of value education is the goal of education that is humanizing human beings, building human plenary, and forming human beings or the whole person. Educational value according to Thapar (2006) briefly be described as "Value education is an education in values and education towards the inculcation of values". Sastrapratedja in Elmubarok (2013: 12) defines the value of education as the planting and development of values in a person, while Mardimadja (1986) defines the value of education as an aid to students to realize and experience values and place it integrally in his whole life.

Hill (Adisusilo, 2013: 70) says that the essence of value education is to lead learners to recognize, unleash, and apply the values, morals and religious beliefs to enter the cultural life of their lifetime. It is clear to Hill that values education should be able to get learners to master the knowledge rooted in their traditional values that can make it enter modern values.

Therefore, value education should help learners experience values and place them in every joint of life. It should be realized that value education is not something that is only added, but something that is essential in the whole process of education. 
Value education is not a separate curriculum taught through several courses but covers the entire educational process. Educational use values even considered as to education itself. So wherever the place is taught the value education will emerge by itself. Value education is the value of education. Sukanta in Elmubarok (2013: 12).

As has been explained earlier that the concept of value education is actually a goal of education that humanizes humans, both us and others. Therefore it then, on the other hand, the value of education can mean educare which means to guide, lead, and lead. Educare education philosophy as it prefers the educational process is not trapped in the material that is imposed on learners, this process becomes a lively activity to accompany, escort, accompanying, guiding, seeks learners to grow and develop to the educational goals. (Elmubarok, 2013: 17)

Value education should help learners to grow and develop into a human person, useful, and influential in society is the very appropriate with the goal of value education that is to form a whole human. Because of these conditions, a comprehensive formulation put forward with the aim to prepare future generations. Values of education aims to assist and deliver learners to independence, maturity, intelligence, human being professional, committed to the values and the basic spirit of sacrifice, faith, and is responsible for the welfare and prosperity of citizens and the nation of Indonesia are very much in line with the goal of education that is to form a whole person.

Based on the basic concept of values education by Theodore Bramelt (Driyarkara, 1991: 46) is education that can become an agent or intermediary for the cultivation of values that exist in the soul. Furthermore, according to Driyarkara educate also interpreted as entering children into the realm of values or entering the world of values into the soul of the child. According to Maslow, there are at least fifteen actualizations of value education results which then become the basic capital to awaken the spirit of benefit in society.

The purpose of education in essential is to humanizing. The educational value should facilitate their students to grow and develop into a more human personal, useful, and influential community, responsible and proactive and cooperative. According to Freire (Mubarok, 2013: 19) states that the true human nature is to be the perpetrator or the subject, go to $\mathrm{n}$ be patient or object.

Still, cases found of violence in education an indicator of educational process or activity, and we still cannot fully realize human values. From here then humanize is an 
attempt to prepare a generation of intelligent reason, emotionally intelligent, and spiritual intelligence, rather than creating a human dwarf, passive, and unable to overcome the problems faced. The right education is an effort to develop the human person to achieve the ultimate goal and also for the benefit of society. In short, it can be said that education is a process by which the value of values gives meaning later in life.

\section{Character Building}

The value of education was not free to do with the character education full swing in Indonesia. Berkowitz (Leming, 2014: 217) defines education as a combination of psychological character impact on the capacity and the tendency of children to become moral agents effective that is socially and individually responsible, virtuous, and dap at self-regulate. Muslich (2011: 84) reveals that character education is a system of planting the values of the character of the citizens of the school, which includes the components of knowledge, awareness or willingness, and actions to implement those values, both against God Almighty, the environment, and the state becomes the human being we are. In line with that, Samani (2011: 45) convey that character education is the process of giving guidance to learners to be a whole person who characterized in the dimensions of heart, though, body, and taste.

Lickona (1991: 14) argues that the educational value/moral produces character, it contains three components of good character, namely: moral knowing, moral feeling moral action. The moral action which includes: the urge to do good, competent, desire, habit (habit). The moral feeling which includes: conscience, confidence, empathy, love, kindness, self-control and humility. Knowing moral which includes moral consciousness, knowledge-moral values, long-term outlook, moral reasoning, decisionmaking and knowledge of learners.

Revelation (Abbas, 2014: 7) says that the character education itself has a higher meaning of moral education, where education is a character in its implementation not only relates to a matter of right or wrong of an act, but more than that character education is to inculcate the habit about the good things in life so that children know and have the awareness to apply the virtues of everyday life. Where in this case a child can be said to have good character if he behaves in accordance with the ethical norms or rules of society. Furthermore, Dharma Kesuma, et al (2011: 5) defines the character education as learning that led to the strengthening and development of the child's behaviour as a whole based on a certain value and is referred to by the school. In line 
with the above opinion, Doni Koesoema A. (2011: 123) argues that character education is the overall relational dynamics between the person with various dimensions, both from within and from outside himself, so that the person is increasingly able to live in freedom so it can be responsible for growth itself as a person and the development of others in their lives.

Character education is an effort that is designed and done right systematically to help students understand the values of human behavior associated with the Almighty God, ourselves, our fellow human beings, the environment, and nationality embodied in thoughts, attitudes, feelings, words, and deeds based on religious norms, laws, manners, culture, and customs (Kemendiknas, 2010: 116).

Based on the Ministry of Education and his little culture there is an 18-character value that must be developed.

Table 1. Value and Description of Education Value

Culture and Character of the Nation

\begin{tabular}{ccl}
\hline No & VALUE & \multicolumn{1}{c}{ DESCRIPTION } \\
\hline 1 & Religious & $\begin{array}{l}\text { Attitudes and behaviours that obedient in } \\
\text { implementing religious teachings that are adhered to, } \\
\text { tolerant of the implementation of other religious } \\
\text { services, and live in harmony with followers of other } \\
\text { religions. }\end{array}$ \\
\hline 2 & Honest & $\begin{array}{l}\text { Behavior-based on an attempt to make himself or } \\
\text { herself trustworthy in words, actions, and work. }\end{array}$ \\
\hline 3 & Tolerance & $\begin{array}{l}\text { Attitudes and actions that respect different religions, } \\
\text { ethnicities, ethnicities, opinions, attitudes, and actions } \\
\text { of others that are different from themselves. }\end{array}$ \\
\hline 4 & Discipline & $\begin{array}{l}\text { Measures that demonstrate orderly behaviour and } \\
\text { abide by various rules and regulations. }\end{array}$ \\
\hline 5 & Hard work & $\begin{array}{l}\text { Behavior that shows a genuine effort to overcome the } \\
\text { obstacles of learning and duty, and complete the tasks } \\
\text { as well as possible. }\end{array}$ \\
\hline 7 & Independent & $\begin{array}{l}\text { Think and do something to generate new ways or } \\
\text { results from something you already have. }\end{array}$ \\
\hline 8 & Democratic & $\begin{array}{l}\text { The waydes and behaviours that are not easy depend on } \\
\text { and dhers in completing tasks }\end{array}$ \\
\hline
\end{tabular}

9 Curiosity Attitudes and actions that always seek to know more deeply and extend from something he learnt, views, and hears. 


\begin{tabular}{|c|c|c|}
\hline 10 & $\begin{array}{c}\text { Spirit of } \\
\text { nationality }\end{array}$ & $\begin{array}{l}\text { The way of thinking, acting, and insight that puts the } \\
\text { interests of the nation and the state above the interests } \\
\text { of self and his group. }\end{array}$ \\
\hline 11 & Love the country & $\begin{array}{l}\text { The way of thinking, being and doing who demonstrate } \\
\text { loyalty, care, and a high appreciation of language, } \\
\text { physical and social environment, culture, economy, and } \\
\text { politics. }\end{array}$ \\
\hline 12 & $\begin{array}{c}\text { Appreciate } \\
\text { Achievement }\end{array}$ & $\begin{array}{l}\text { Attitudes and actions that drive him to produce } \\
\text { something useful for society, and recognize, and respect } \\
\text { the success of others. }\end{array}$ \\
\hline 13 & $\begin{array}{c}\text { Friendly / } \\
\text { Communicative }\end{array}$ & $\begin{array}{l}\text { Actions that show the pleasure of talking, getting along, } \\
\text { and working with others. }\end{array}$ \\
\hline 14 & Love peace & $\begin{array}{l}\text { Attitudes, words, and actions that cause others to feel } \\
\text { happy and secure for their presence. }\end{array}$ \\
\hline 15 & Like to read & $\begin{array}{l}\text { The habit of taking the time to read the various } \\
\text { readings that give good to him. }\end{array}$ \\
\hline 16 & $\begin{array}{c}\text { Environmental } \\
\text { care }\end{array}$ & $\begin{array}{l}\text { Attitudes and actions that always try to prevent } \\
\text { damage to the surrounding natural environment, and } \\
\text { development efforts to repair the already existing } \\
\text { natural damage. }\end{array}$ \\
\hline 17 & Social care & $\begin{array}{l}\text { Attitudes and actions that always want to provide } \\
\text { assistance to others and communities in need. }\end{array}$ \\
\hline 18 & Responsible & $\begin{array}{l}\text { Attitudes and behaviour of a person to carry out his } \\
\text { duties and obligations, which he should do, to himself, } \\
\text { society, environment (nature, social and cultural), the } \\
\text { state and God Almighty. }\end{array}$ \\
\hline
\end{tabular}

Source: Curriculum Center of the Ministry of National Education

\section{Philosophy of Life Banjar}

\section{Gawi Manuntung}

Gawi manuntung a principle very closely with everyday life Banjar, where this principle even became the motto of the city of Balikpapan in East Kalimantan. Based Gawi manuntung sentence consists of two words which are words Gawi which means employment or work and manuntung which means complete. So we can say that Gawi manuntung means that any work that began then to be resolved. Based on this, it is sufficient to describe a work ethic of Banjar people themselves who must be consistent in doing each work until finished. In my view, this case also illustrates the attitude of responsibility and hard work, which is five points are highlighted character education, so the five values that accompany these principles are relevant to integrate the value and habit of teaching history. 


\begin{tabular}{|c|l|}
\hline \multirow{2}{*}{ Responsible } & $\begin{array}{l}\text { Attitudes and behaviour of a person to carry } \\
\text { out his duties and obligations, which he should } \\
\text { do, to himself, society, environment (nature, } \\
\text { social and cultural), the state and God Almighty }\end{array}$ \\
\hline Hard work & $\begin{array}{l}\text { Attitudes and behaviours that demonstrate } \\
\text { genuine efforts to overcome barriers to } \\
\text { learning and tasks, as well as complete tasks to } \\
\text { the maximum extent, is able to the maximum } \\
\text { limit of the targets that have been determined, } \\
\text { both time and quality of work. }\end{array}$ \\
\hline Diligent & $\begin{array}{l}\text { Attitudes and behaviours that show the craft, } \\
\text { sincerity and continuously in learning and } \\
\text { doing the task. }\end{array}$ \\
\hline Creative & $\begin{array}{l}\text { Think and do something to generate new ways } \\
\text { or results from something you already have. }\end{array}$ \\
\hline Discipline & $\begin{array}{l}\text { Measures that demonstrate orderly behaviour } \\
\text { and abide by various rules and regulations. }\end{array}$ \\
\hline
\end{tabular}

\section{Waja sampai Kaputing}

Waja sampai kaputing, this term is a principle which is very popular among people in Banjar. This sentence seemed to be a sparkling spirit for Banjar People. This sentence is even the motto of the University of Lambung Mangkurat Banjarmasin, this sentence is one of the sentence encouraged by Prince Antasari in Banjar War.

Waja sampai kaputing means that efforts to end. The other meaning of waja sampai kaputing cites the opinion of Sarbaini (2014: 2) determination like steel from the base to the tip. In the context of the Banjar struggle, this phrase means a struggle that never goes out or stops with the last drop of blood, or until the achievement of a goal. This sentence is very rich in meaning which is a depiction of a work ethic of Banjar which implies when starting a containing mean when starting a job then does it to complete its implementation. Everyone is responsible for completing his work not to hang. This motto is a symbol that the people of South Kalimantan are always diligent in working, doing everything with sincerity, the sense of ability and consequence without stopping in the middle of the road, must arrive at the goal to be achieved. Therefore it is always based on the determination and tough, like steel (waja) from the starting point (end) up to the point of destination (kaputing), and unlawful stops midway (haram manyarah). 
As previously principles of gawi manuntun, waja sampai kaputing not separated meaning and value. So that this principle can be analyzed that there are at least. There are six character values contained therein and can integrate into teaching history, especially the history of the struggle of good people in the War of Borneo Banjar or physical revolution.

The values contained in waja sampai kaputing, namely:

\begin{tabular}{|c|l|}
\hline Hard work & $\begin{array}{l}\text { Attitudes and behaviours that demonstrate genuine } \\
\text { efforts to overcome barriers to learning and tasks, as } \\
\text { well as complete tasks to the maximum extent, is } \\
\text { able to the maximum limit of the targets that have } \\
\text { been determined, both time and quality of work. }\end{array}$ \\
\hline Tough & $\begin{array}{l}\text { Attitudes and behaviours that demonstrate genuine } \\
\text { efforts to overcome barriers to learning and tasks } \\
\text { and complete tasks as well as possible }\end{array}$ \\
\hline Honest & $\begin{array}{l}\text { Attitudes and behaviours that are based on an } \\
\text { attempt to establish themselves as people who are } \\
\text { always trustworthy in words, actions, and work }\end{array}$ \\
\hline Diligent & $\begin{array}{l}\text { Attitudes and behaviours that show the craft, } \\
\text { sincerity and continuously in learning and doing the } \\
\text { task. }\end{array}$ \\
\hline Awkward Answer & $\begin{array}{l}\text { Attitudes and behaviour of a person to carry out his } \\
\text { duties and obligations, which he should do, to } \\
\text { himself, society, environment (nature, social and } \\
\text { cultural), the state and God Almighty }\end{array}$ \\
\hline Discipline & $\begin{array}{l}\text { Attitudes and actions that demonstrate the } \\
\text { behaviour of obedient/obedient to various } \\
\text { provisions and regulations }\end{array}$ \\
\hline
\end{tabular}

\section{Sarabakawa: Kawa Baucap, Kawa Manggawi, Kawa Manyandang}

Sarabakawa is the motto of Tabalong Regency, whereas before this principle is a very familiar principle of Banjar society. Where this sentence implies baucap kawa, which means it can say, could say or could promise. Then kawa menggawi, which means it can do, and kawa manyandang, which means it can give an account is understood as the ability responsibility for the idea and what she is doing. Abstinence run amid the battlefield never leaves the fight before it completes battle arena and fights it. It also means ready to confront all the consequences for what he has done, will not run away from responsibility. So that, when coupled to the sentence, would mean that someone should be accountable for every word by implementing the best way according to what was said or planned. 
If you look at the two previous philosophies then it is not unlike this where it very clearly describes the work ethic that must be owned by the Banjar in carrying out every work. Where we can clearly see that there are at least 5 values of characters contained in it.

The value of these characters are:

\begin{tabular}{|c|l|}
\hline Religious & $\begin{array}{l}\text { Attitudes and behaviours that obedient in carrying } \\
\text { out the teachings of their religion, the practice of } \\
\text { religion tolerant of others, and live in harmony with } \\
\text { other faiths. }\end{array}$ \\
\hline To be responsible & $\begin{array}{l}\text { Attitudes and behaviour of a person to carry out his } \\
\text { duties and obligations, which he should do, to } \\
\text { himself, society, environment (nature, social and } \\
\text { cultural). }\end{array}$ \\
\hline Diligent & $\begin{array}{l}\text { Attitudes and behaviours that show the craft, } \\
\text { sincerity and continuously in learning and doing the } \\
\text { task. }\end{array}$ \\
\hline Honest & $\begin{array}{l}\text { Attitudes and behaviours that are based on an } \\
\text { attempt to establish themselves as people who are } \\
\text { always trustworthy in words, actions, and work }\end{array}$ \\
\hline Hard work & $\begin{array}{l}\text { Behavior that shows a genuine effort to overcome the } \\
\text { obstacles of learning and duty, and complete the } \\
\text { tasks as well as possible. }\end{array}$ \\
\hline Creative & $\begin{array}{l}\text { Think and do something to generate new ways or } \\
\text { results from something you already have. }\end{array}$ \\
\hline
\end{tabular}

\section{Integration of the values of the Banjar life philosophy in Historical Learning}

If seen in the perspective of the principles or views of the life of the Banjar then printed clearly the depiction of very high moral principles and a strong work ethic, which is a mandatory consequence of the teleological aspect of his life in the future in order to obtain a quality of welfare. Citing the opinion of Alfani Daud (Hadi, 2016: 214) the purpose of life Banjar there are two, namely prosperity in the "future closer", and well-being in" times front of the far". Welfare in times a close front is a prosperous life on the world, while the welfare of the times the distant front is a prosperous life in the hereafter. Of the two kinds of goals this welfare, a priority the main is the second goal that is the orientation of the hereafter. From the explanation, it is very clear that the life of Banjar always tries to balance between world life and hereafter. So it is not surprising that Banjar people are seen as a fairly religious figure in running his life. As in moral principles the hard work of the Banjar people underpinning their view that life it is a 
challenge that should be faced with effort, with work, then a valuable way of life "Of struggle" in the context of ethics, clear containing positive values.

Of the three principles of the Banjar which has been described previously are the principles that are very closely related to the life of Banjar people every day. These principles even become comrades of struggle by the leaders of regional fighters against the tyranny of the colonial nation. Therefore it is not wrong if the values at the principle of life are then integrated to Banjar in history, both national history and local history. In the implementation of these three principles can be directly integrated into the learning of history through the direct enthusiasm of the learners and also through the habituation of the class.

Direct implementation in question is carried out through the discussion implantation on the history of the struggle, especially the history of the struggle in South Kalimantan through three learning phases; planning, process, and evaluation. As has been explained that the implementation of history education is a subject that is very close to the value of education and the character of the nation. Therefore it is not surprising if history later came out as an important focus of national character formation. From the local history of struggle against colonialism are many aspects that can be seen in the process. So it can take a sample of the material struggle of the people against the invaders before the 20th century, which in the context of national history also discussed therein struggle Banjar Banjar War which occurred during 1859-1906) of this struggle emerged figures Pangeran Antasari valiant and can be lived each struggle. Principle waja sampai kaputing presented by Pangeran Antasari in Banjar War' fighting spirit can burn Banjar. The spirit and character waja sampai kaputing are then that integrate directly into the teaching of history so that students not only understand the learning materials of this course will but also directed can appreciate the value of the struggle of Pangeran Antasari.

Excitement waja sampai kaputing, gawi manuntung, and sarabakawa when seen from the context it is clear discuss the ethos or spirit of Banjar. As a teacher who is an aspect of education that has nature as an institution of cultural transformation, it should be mandatory to continue to preserve the value and character of Banjar people who are religious, responsible, diligent, honest, creative, and always worked hard. Where these values may continue to be integrated into the learning process with the assessment aspect of attitude becomes the focal point of the curriculum in 2013 
As has been explained that the implementation of history education is a subject that is very close to the value of education and the character of the nation. Therefore it is not surprising if history later came out as an important focus of national character formation. From the local history of struggle against colonialism are many aspects that can be seen in the process. So it can take a sample of the material struggle of the people against the invaders before the 20th century, which in the context of national history also discussed therein struggle Banjar Banjar War which occurred during 1859-1906) of this struggle emerged figures Pangeran Antasari valiant and can be lived each struggle. The principle of waja sampai kaputing presented by Pangeran Antasari in Banjar War' fighting spirit can burn Banjar. The spirit and character waja sampai kaputing are then that integrate directly into the teaching of history so that students not only understand the learning materials of this course will but also directed appreciate the value of the struggle of Pangeran Antasari.

Excitement waja sampai kaputing, gawi manuntung, and sarabakawa when seen from the context it is clear discuss the ethos or spirit of Banjar. As a teacher who is an aspect of education that has nature as an institution of cultural transformation, it should be mandatory to continue to preserve the value and character of Banjar people who are religious, responsible, diligent, honest, creative, and always worked hard. Where these values may continue to be integrated into the learning process with the assessment aspect of attitude becomes the focal point of the curriculum in 2013.

\section{CONCLUSION}

Gawi manuntung, waja sampai kaputing, and sarabakawa describes a work ethic and character Banjar responsible, work hard, disciplined, diligent, honest, creative, disciplined, responsible, and with the religious attitude is good, so these values should not only limited display area watchword alone but also can be carried out directly in the context of education, especially in teaching history is directly in contact with the spirit waja sampai kaputing motto of Pangeran Antasari in Banjar War. Learners are expected to not only know the facts of history but also be able to appreciate directly the principles that continue to be held by the fighters in kaimantan South so as to continue to integrate the value of life principle Banjar are loaded with value, maybe a guard for the young generation in Kalimantan South in the face of the swift currents implicated global directly against the moral obscurity and national character. 


\section{REFERENCES}

Abbas, E.W. 2014. "Kurikulum Pendidikan IPS berbasis Pendidikan Karakter" dalam Pendidikan Karakter. Bandung: Niaga Sarana Mandiri.

Adisusilo, S. 2013. Pembelajaran Nilai- Karakter. Jakarta: PT. Rajagrafindo.

Amri, S., dkk. 2013. Implementasi Pendidikan Karakter dalam Pembelajaran. Jakarta: Rajawali Press.

Aziz, H.A. 2013. Pendidikan Karakter Berpusat Pada Hati. Jakarta: Al Mawardi Prima.

Driyarkara, N. 1980. Driyarkara tentang Pendidikan. Yogyakarta: Penerbit Kanisius.

Kesuma, D., dkk. 2011. Pendidikan Karakter: Kajian Teori dan Praktik di Sekolah. Bandung: PT Remaja Rosdakarya.

Kesuma, D. A. 2009. Pendidikan Karakter di Zaman Keblinger. Jakarta: Grasindo.

Lickona, T. 1992. Pendidikan Karakter: Panduan Lengkap Mendidik Siswa Menjadi Pintar dan Baik. Jakarta: Nusamedia

Lickona, T. 1992. Character Matters. Newyork: Bantaam Book.

Mubarok, Z. 2013. Membumikan Pendidikan Nilai. Bandung: Alfabeta.

Mudyahardjo, R. 2009. Pengantar Pendidikan. Jakarta: Rajawali Press.

Muslich, M. 2011. Pendidikan Karakter: Menjawab Tantangan Krisis Multidimensional. Jakarta: Bumi Aksara.

Purwanto, S. A., 2014. Revolusi Mental sebagai Strategi Kebudayaan, Bunga Rampai Seminar Nasional Kebudayaan 2014. Jakarta: Pusat Penelitian dan Pengembangan Kebudayaan Kemendikbud.

Hasan, S.H. 2012. Pendidikan Sejarah Untuk Memperkuat Pendidikan Karakter. Jurnal Paramita Vol. 22 No. 1 - Januari 2012.

Saibaini. 2014. Dari Wasaka Menuju Taluba: Konseptualisasi Nilai-Nilai Luhur Suku Banjar Sebagai Sosok Karakter Harapan 'Urang Banua' Perspektif Etnopedagogi. Makalah untuk Seminar Internasional Pendidikan Karakter dalam rangka Dies Natalis FKIP KE 57 tanggal 24 Mei 2014 di Gedung Serba Guna Unlam Banjarmasin.

Samani, M. \& Hariyanto. 2012. Konsep dan Model Pendidikan Karakter. Bandung: PT Remaja Rosda Karya.

Hadi, S. 2015. Studi Etika Tentang Ajaran-ajaran Moral Masyarakat Banjar. Jurnal Tashwir Vol. 3 No. 6, April - Juni 2015.

Wahyu. 2014. Pendidikan Karakter. Bandung: Niaga Sarana Mandiri. 